\title{
ガラス繊維強化エポキシ樹脂複合材料に 潜在する電子線照射による劣化
}

\author{
宇田川 昂*，丸山 誠次**，貴家 恒男***，瀬口 忠男**** \\ (1993 年 5 月 26 日受付)
}

\section{Latent Degradation Induced in Glass Fiber-Reinforced Epoxy Resin Composites by Electron Irradiation}

\author{
A. Udagawa, ${ }^{*}$ S. Maruyama, ${ }^{* *}$ T. Sasuga*** and T. Seguchi**** \\ (Received May 26, 1993)
}

\begin{abstract}
Radiation effects on mechanical properties of the glass fiber-reinforced bisphenol-A type epoxy resin were studied. The threshold dose, where 3-point bending strength started to change, was $30 \mathrm{MGy}$. Radiation-induced latent degradation within the threshold dose was observed by the analysis of differential modulus from the curve of load against displacement. The differential modulus curves could be divided into two displacement regions. It was concluded through the data of water absorption and observations with scanning acoustic microscopes, that the two regions were due to the debonding of matrix-fiber interface and the micro-cracking in the matrix resin, respectively.
\end{abstract}

\section{1. 緒言}

ガラス纎維強化プラスチック（GFRP）は，電気絶縁 性と高比強度を有することから，核融合邩の超電導マグ ネット用絶縁材料に適用される予定である，材料の選択 に際しては, 耐放射線性評価が重要な課題となってい $る^{11}$. 実使用環境からこの材料は，中性子とガンマ線に より極低温下で 30 50 MGy の放射線に晒されるものと 推定されている. また，この間の強度は $1,000 \mathrm{MPa}$ を 保持することが必要とされている22. さらに，超電導磁 石の構造上の制約から,さほど高度でない条件で成形加 工できる材料であることが望まれている，したがって，

$*, * * *, * * * *$ 日本原子力研究所高崎研究所 (370-12 高 崎市綿貫町 1233)

Japan Atomic Energy Research Institute, 1233

Watanuki-cho, Takasaki 370-12

* 材料開発部総括主查 Chief General, $* * *$ 材 料開発部主任研究員 Principal Scientist, $* * * *$ 極限材料研究室長 Head, Advanced Materials Laboratory

** 富士重工業(侏航空宇宙事業本部材料研究第 2 課 (302 宇都宮市陽南 1-1-11)

Senior Engineer, Fuji Heavy Industries, Ltd.
マトリックスとしてェポキシ樹脂を用いる場合は低温硬 化型の樹脂, 例えばビスフェノール A または F 系を選択 することになる，しかし，著者らのこれまでの研究で は，耐放射線性は高温硬化型の方が低温硬化型より高い ことがわかっている3゙.

一方，エポキシ樹脂を含め, 高分子材料の極低温照射 下に拈ける放射線劣化は，室溫下のそれに比べて著しく 小さくなることが明らかにされている4)。 このことを考 虑すると, 超電導磁石の絶縁材料として低温硬化型エポ キシ樹脂の適用も期待できると考えられる.

複合材料の耐放射線性は通常, 機械特性の低下が始ま る線量，すなわち放射線劣化の敷居值から評価されてい る. しかし，この範囲でも放射線損傷は進んでいると思 われるが，巨視的な物性変化として現れてこないため明 らかにされていない,5,6).

本報告は，低温硬化型エボキシ樹脂系 GFRP の敷居 值以下の線量域に潜在する放射線劣化を, 三点曲げ試験 により顕在化させるち法について検討し，さらにその 劣化のメカニズムを超音波顕微鏡（SAM : Scanning Acoustic Microscope) 観察と吸水試験により考察した。 


\section{2. 実 験 方 法}

\subsection{FRP の調製}

GFRP の調製は，ジシアンジアミド (DICY) を硬化 剤とするビスフェノールA系ェポキシ樹脂 (DGEBA) をマトリックスとする市販のブリプレグ（YRC G120/ F6986S03-S920NM)を使用した。成形は所定の条件下で 真空バッグ法により行い, 厚さ約 $2.3 \mathrm{~mm}\left(V_{f}=40 \%\right)$ のパネルに加工した．このパネルからダイヤモンドカッ ターで幅 $6.5 \mathrm{~mm}$, 長さ $70 \mathrm{~mm}$ に切り出したものを試 験片として用いた。

\section{2 放射線照射}

放射線照射装置は最大定格 $3 \mathrm{MeV}, 25 \mathrm{~mA}$ の電子加 速器「ダイナミトロンIEA-3000-25-2」を用いた. 照射 は空気中で行ったが，試験片の照射中の温度上昇を抑制 するため, 加速電圧 $2.0 \mathrm{MV}$, 全電子線電流 $2.86 \mathrm{~mA}$ とし, 試験片を加速管の空から垂直に $40 \mathrm{~cm}$ 下の線量率 $5 \mathrm{kGy} / \mathrm{s}$ の位置に並べて行った. また, 試験片の熱伝達 を良くするために，1片ごとにアルミホイルで包み，ス テンレス製水冷板に銀ペースト（商品名：DOTITE Type D-550）を用いて接着固定して照射を行った. 照 射中の試験片の温度は, この条件で $50^{\circ} \mathrm{C}$ 以下に保持し た.

\section{3 機械特性試験}

インストロン 4301 型引張り試験機を用いて三点曲げ 試験による最大曲げ強さと弾性率の変化を求めた. 测定 は支点間距離と試験片厚さの比を 25 にとり, クロスへ ッド移動速度 $2 \mathrm{~mm} / \mathrm{min}$ で行い, 5 個の平均値をとっ た.

\subsection{SAM による観察}

超音波顕微鏡はオリンパス Type UH3 を用いて, 400 $\mathrm{MHz}$ の音響レンズによる試料表面付近の画像を観察し た.

\section{5 吸水率の測定}

試験片の吸水率は, $50^{\circ} \mathrm{C}$ の恒温槽で 24 時間乾燥後デ シヶータ中で冷却して試験前の質量を計り,これを $50^{\circ} \mathrm{C}$ の温水中に所定時間浸漬した後の質量増加率から求め た.

\section{3. 結果と考察}

\section{1 照射による機械特性の変化}

GFRP の電子線照射による吸収線量と三点曲げ強度お よび初期（変位 $10 \%$ 以下の直線部分）の勾配から求め た曲げ弾性率の関係を Fig. 1 に示す. Fig.1 には低温に

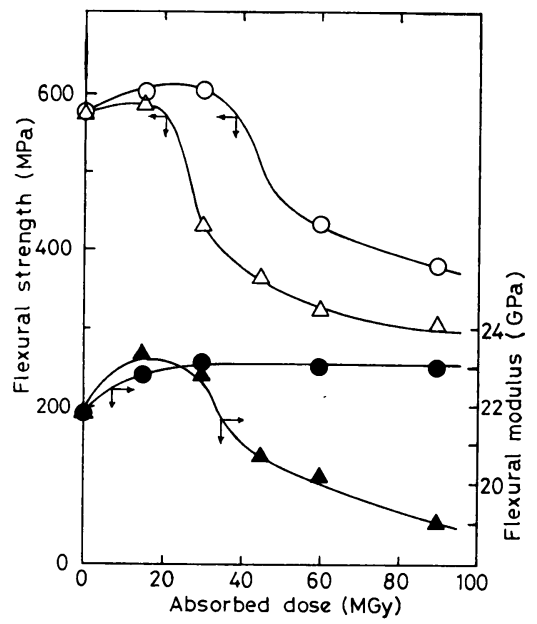

Fig.1 Dose dependence of flexural strength and modulus of glass/epoxy composite, ( $O$, -) non-treated after irradiation, $(\Delta, \Delta)$ dipped in liquid nitrogen for 10 minutes after irradiation.

晒したときの熱衝撃が曲げ強度に与える影響を調べるた め，照射した試験片を液体窒素 $(77 \mathrm{~K})$ 中に投入し，10 分後デシヶータ中で室温に戻してから测定した場合の結 果を併せて示した。

低温熱衝撃を与えていない試料の曲げ強度の変化を見 ると, 吸収線量 $30 \mathrm{MGy}$ までの範囲では未照射試料に比 べてやや大きくなり，30 MGy を越えると急に低下する ことがわかる. この傾向は, ビスフェノール $\mathrm{A}$ 系のェポ キシ樹脂をマトリックスとして用いた場合に見られ る7). すなわち, この材料では $30 \mathrm{MGy}$ が敷居線量とな っており，この範囲の照射では劣化が起きていないと判 断される. 曲げ弾性率は荷重一変位曲線の初期の勾配か ら求める限り, 照射初期の低い線量では未照射時に比べ て僅かに増大する傾向を示し，線量の増大に対してほほ 一定の值を保持している. したがって，仮に敷居値まで の範囲に放射線劣化が潜在しているとしても，これらの 結果から,それは判断し難い。

一方，低温熱衝撃を与えた場合，15 MGy を越えると 曲げ強度が著しく低下している．また，初期の勾配から 求めた曲げ弾性率も，低温熱衝撃により著しい低下を示 すことが分かる.これは，放射線劣化が敷居值の範用に おいて潜在していることを示唆している.

\section{2 敷居値の範囲内にある荷重一变位曲線の特徵}

Fig. 2 は末照射と $30 \mathrm{MGy}$ 照射した試料の代表的な荷 重一变位曲線を示す．敷居値の範囲内で荷重-変位曲線を 


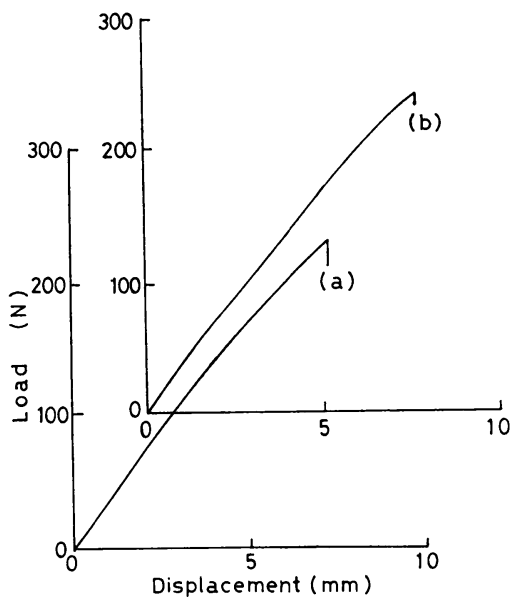

Fig.2 Typical load-displacement curves for glass/epoxy composite, (a) non-irradiated, (b) irradiated with $30 \mathrm{MGy}$.

見比べても，相互に有意差があるとはいい難い，そこ で, 荷重-変位曲線の変位 0 から $100 \%$ （破断時の变位） までを $5 \%$ ごとに分割し，それぞれの公配から弾性率の 変化を求めた。この值を微分弾性率と定義し, 変位に対 してプロットした結果を Fig. 3 に示す. 敷居值の範囲を 越えた $60 \mathrm{MGy}$ の結果も併せて示した．末照射試料の場 合, 微分弾性率は変位 $20 \%$ まで一定值を保ち，その後 は徐々に低下する，これに刘し，照射した試料は線量が 增すと，より少ない变位で微分弾性率の低下が起こるこ とがわかる.これは放射線照射によって，GFRPに損傷 が起きたことを反映するもので,すでに微視的な破壊が 進行している領域と考兄られる.ここで, 変位 10 30\% での急激な弾性特性の低下を第一变形領域と定義する. また, 変位 30 60\% の間では，微分弾性率が再びほぼ 一定になっている. 第一変形領域とは別のモードで破壊 が起きているためと推定され，これを第二変形領域と定 義する. 変位 55\% はマクロな意味で試験片が初期破壊 へ導かれると思われる特異点であり, 吸収線量に依存せ ず微分弾性率はほぼ同じ值を示す。放射線劣化と,この 第一変形領域および第二変形領域についての関係を以下 に述べる.

\subsection{SAM による欠陥観察}

SAM は非破壊的镍察手段として用いるのが理想的で あるが，照射した GFRP 試料をそのます観察しても敷 居值の範囲内では変化が認められなかった．そこで,

Fig. 3 において第二変形領域に入る直前まで曲げ負荷を 与えた後, 負荷を解放した試料の引張り側の表面（荷重

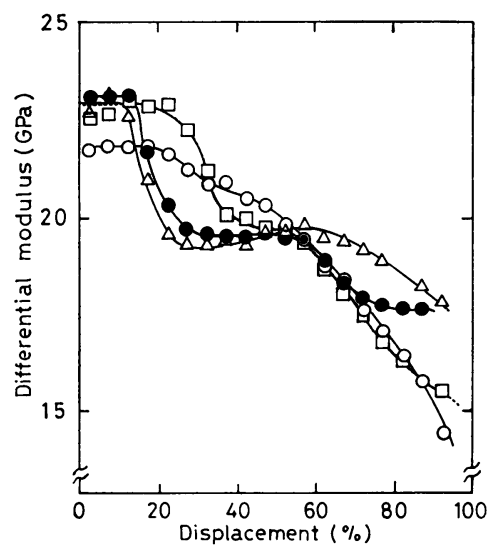

Fig. 3 Differential modulus analyzed from loaddisplacement curve as a function of displacement. (O) non-irradiated, ( $\square$ ) 15

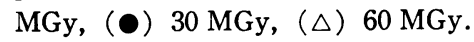

点の裏面）を観察したが，無負荷試料との問で変化は認 められなかった. 次いで, 第二変形領域の変位 $50 \%$ ま で負荷を与えた.この試験片からは, Fig. 4(a)〜 (d) に示 すマイクロクラックの発生が観察できた。(a)は未照射試 料で, この場合変形領域がないためマイクロクラックは ない（b)，(c)，(d)はそれぞれ 15，30，60 MGy 照射した 試料の絬果である. 線量の增大と共にマイクロクラック が増加している.この結果から, Fig. 3 において照射試 料に特有の第二変形領域が現れる原因は, マトリックス にクラックが発生するためと考えられる.ここで示した クラックはいずれも開口部のあるもので, 光学顕微鏡で も観察は可能であるが, SAM の場合, 補強繊維とマト リックスの弾性的な性質が極端に異なるためコントラス トが高く, 縺維の配列とマトリックスに発生したクラッ クの位置関係を含めた画像が明瞭に得られた. 以上の結 果から, 第一変形領域における弾性率の急激な低下は, マトリックスから繊維が引き抜かれて界面で擦れが起き たために現れるものと推測されるが，SAM による画像 観察からこれを判断することはできなかった.

Fig. 5(a)〜(d) は, 低温熱衝撃を与えた各吸収線量の試 料について観察した SAM 写真を示す.この結果から, $30 \mathrm{MGy}$ 以上照射した試料は, 熱衝撃によるマイクロク ラックがランダムに発生しており，その数は線量に伴っ て增えていることがわかる、すなわち，照射した試料に 低温熱衝撃を与えた場合の曲げ強度と弾性率の低下は, 熱衝撃によって発生したマイクロクラックに起因すると 解釈でき，敷居值の範囲にあってもマトリックスは照射 


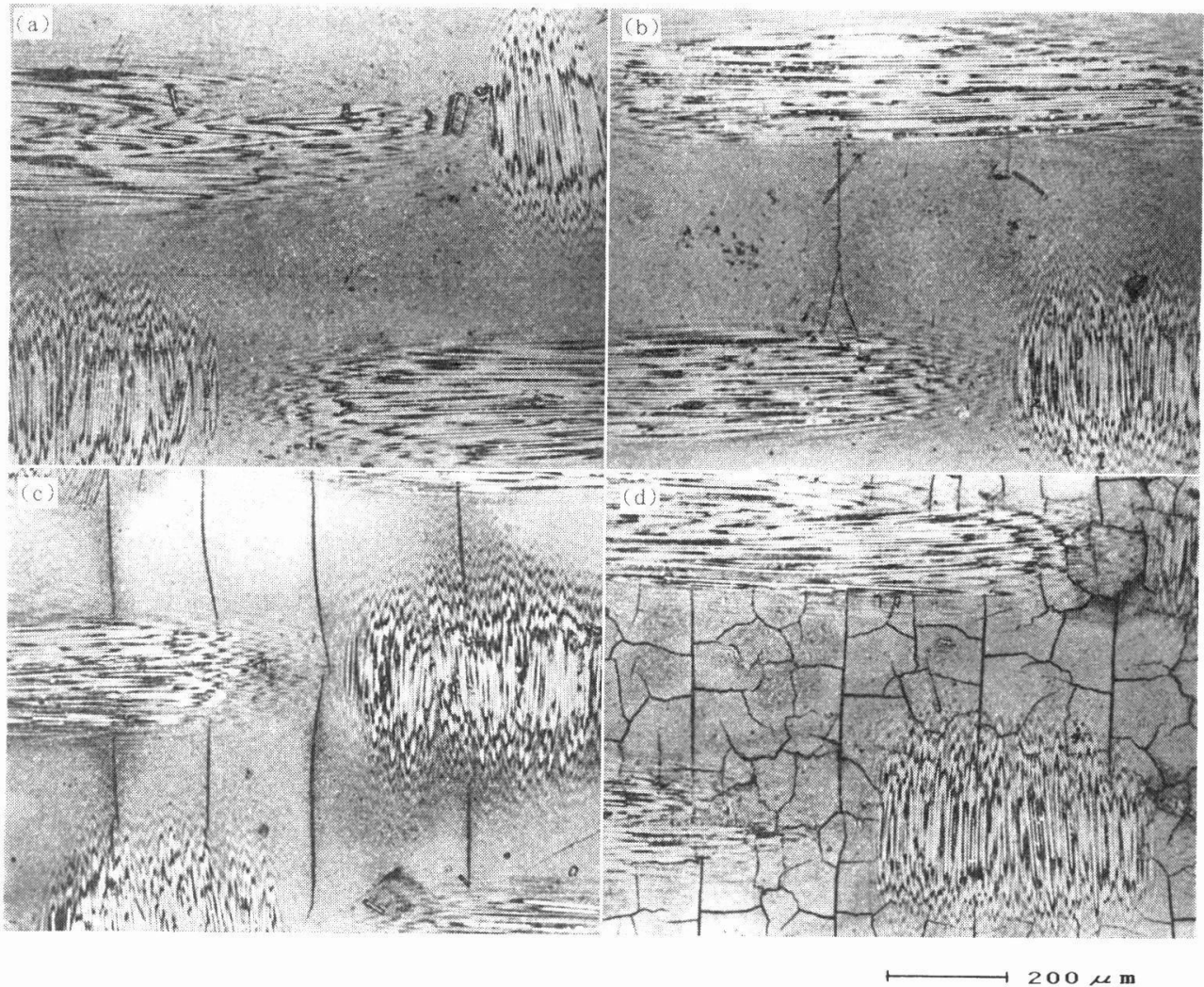

Fig. 4 Scanning acoustic microscopic images for the glass/epoxy composite after one cycle loading to $50 \%$ displacement of ultimate strain. (a) non-irradiated, (b) $15 \mathrm{MGy}$, (c) $30 \mathrm{MGy}$, (d) $60 \mathrm{MGy}$.

Table 1 Water absorption for EB irradiated glass/epoxy composites before and after loading to $50 \%$ displacement of ultimate strain.

Water absorption (\% of weight gain)

\begin{tabular}{lcccc}
\hline Absorbed dose (MGy) & Unirrad. & 15 & 30 & 60 \\
\hline Before loading & 0.05 & 0.52 & 1.12 & 1.99 \\
After loading & 0.05 & 0.63 & 1.10 & 2.05 \\
\hline
\end{tabular}

Water absorption : GFRP specimens are held for $2 \mathrm{~h}$ in $50^{\circ} \mathrm{C}$ water.

によってかなり脆化していることを示唆している.

\section{4 照射試料の吸水率}

マイクロクラックの発生は吸水率の增大をもたらすも のと考学らる. Fig. 3 の车験と全く同じ条件の変位を 与えてあらかじめ試験片にクラックを作り, $50^{\circ} \mathrm{C}$ の温水 中に执ける吸水率を時間に対して調べた結果をFig. 6 に 示す. Table 1 は照射したたけけのるの，なおちクラッ
クのない試料について測定した吸水率を，クラックがあ る場合と比較して示した. Fig. 6 からは，クラックの量 に対応して吸水率が増大しているように見えるが, Table 1 からわかるよらに, 吸水率の増大はクラックと は無関係であり，吸収線量にだけ依存している。 Fig.6 から吸水の初期速度を求めて線量に対してプロットした 結果を Fig. 7 に示す. 吸水速度は線量に比例して増大す 


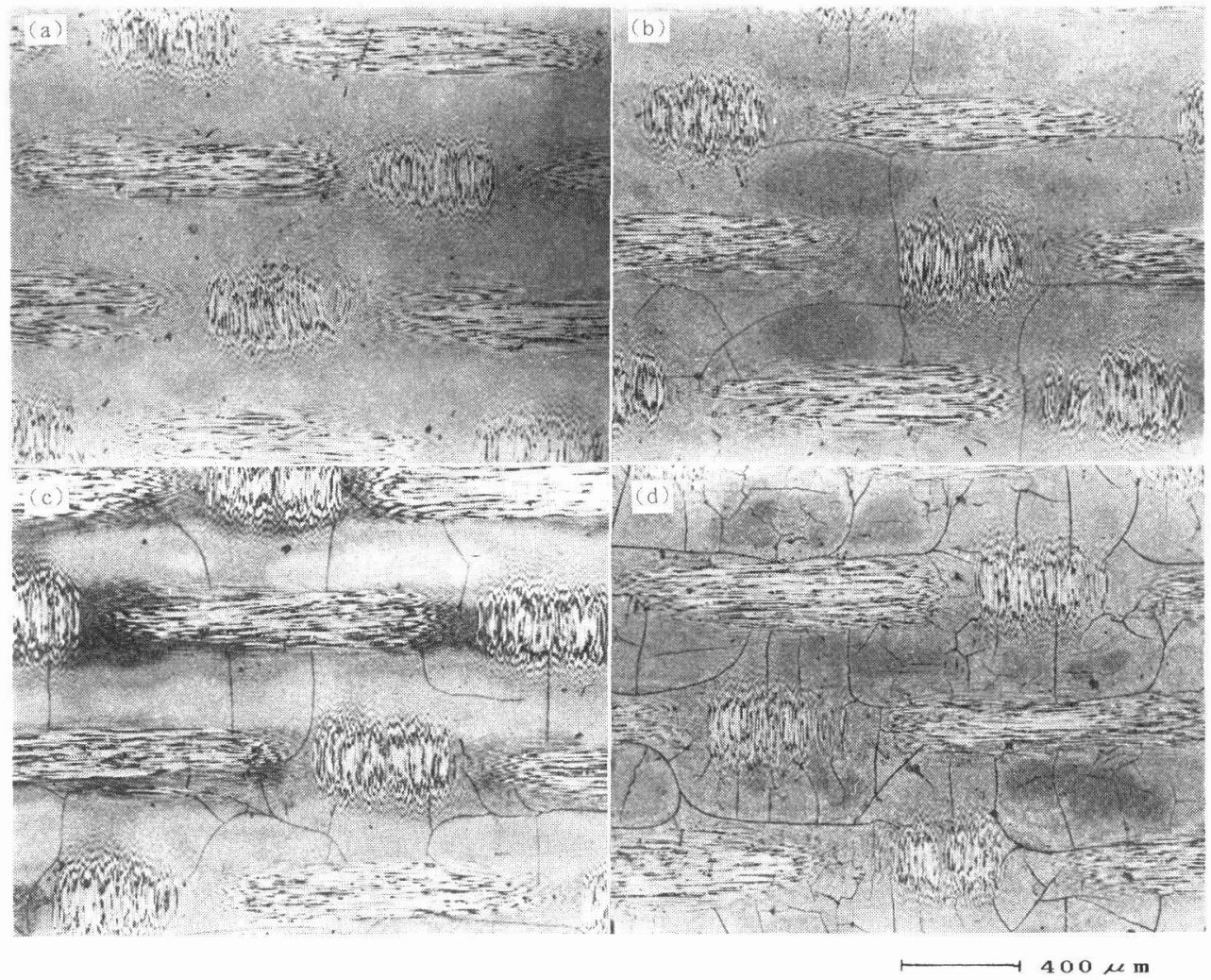

Fig. 5 Scanning acoustic microscopic images for the glass/epoxy composite by immersion in liquid nitrogen for 10 minutes after $\mathrm{EB}$ irradiation. (a) 15 'MGy, (b) $30 \mathrm{MGy}$, (c) $45 \mathrm{MGy}$, (d) $60 \mathrm{MGy}$.

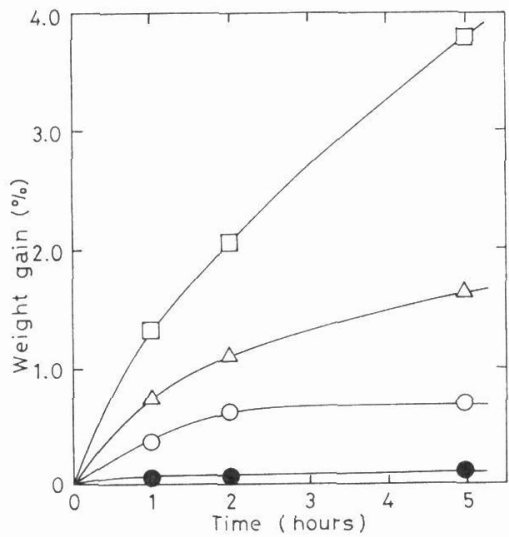

Fig. 6 Water uptake in glass/epoxy composites vs. immersion time in water at $50^{\circ} \mathrm{C}$. (•) non-irradiated, (O) $15 \mathrm{MGy},(\Delta)$ $30 \mathrm{MGy}$, ( $\square$ ) $60 \mathrm{MGy}$.

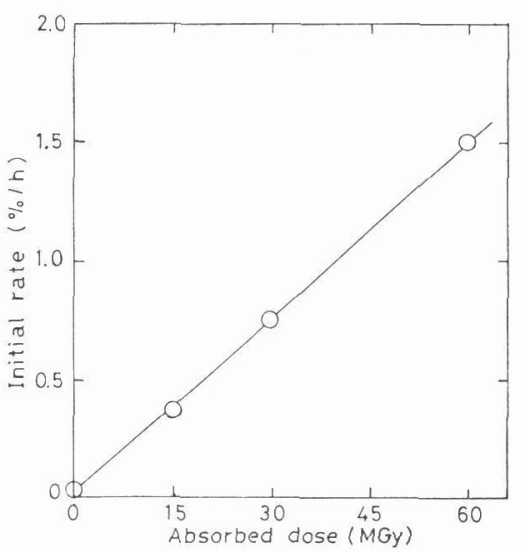

Fig. 7 Initial rate of water uptake in glass/epoxy composites as function of $\mathrm{EB}$ absorbed dose. 
ることがわかる。 また，マトリックス樹脂単体約 1.1 ( $\mathrm{g}$ ) から求めた $50^{\circ} \mathrm{C} ， 2$ 時間の吸水率は未照射ならびに 15 MGy 照射した場合のいずれも $0.2 \%$ であり，照射によ る吸水率の増加はなかった. したがって, 吸水率は繊維一 樹脂界面の劣化による親水性の増大に支配されているも のと考えられ，Fig. 3 に拉ける第一变形領域と密接に関 係するものと結論される. 一方, 前述の低温熱衝撃でマ イクロクラックが発生して低下した弾性率は約 $20 \mathrm{GPa}$ であり，この値はすでに述べた第二変形領域の值に相当 している.このことは, 低温熱衝撃によるマイクロクラ ックがすでに緎維-樹脂界面の剩離も伴っていることを 示していると考えられる.

\section{4. 結}

\section{言}

ビスフェノール A系エポキシ樹脂をマトリックスとす る市販のプリブレグ (YRC, G120/F6986S03-S920NM) から成形した GFRP は，三点曲げ強さによる放射線劣

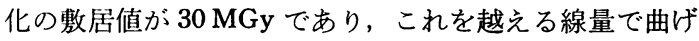
強さが低下した，本研究では特に，敷居值の範囲にある 劣化を顕在化する方法と, 顕在化した現象に対する放射 線少化のメカニズムとの関係を SAM 観察と吸水率測定 により詳細に検討したところ以下の結論を得た。

（1）敷居値の範囲では曲げの荷重一変位曲線から求めた 微分弾性率を調べることにより，放射線劣化に基づく二
つの変形領域を見出すことができ，それぞれ繊維と樹脂 の界面の剥離とマトリックスに発生するマイクロクラッ クに対応していることがわかった。

(2) 吸水率はマイクロクラックの有無に関係なく吸収 線量にのみ依存して増大することから，吸水率は䋐維と 樹脂の界面の劣化に支配されていることがわかった。

（3）超音波顕微鏡によるマイクロクラックの観察は画 像のコントラストが高いため, 繊維との位置関係を鮮明 に識別することができた.

\section{参考文 献}

1) B.S. Brown : J. Nucl. Mater., 97 (1981), 1.

2) 吉田 清 : 応用放射線化学シンポジウム「放射線 環境と高分子材料」講演要旨集, 日本放射線化学 会主催（平成 3 年 1 月 17 日), pp. 13-16.

3）瀬口忠男: 日本複合材料学会誌，15，2(1989), 49-55.

4) H. Kudoh, N. Kasai, T. Sasuga \& T. Seguchi : Radiat. Phys. Chem., 43, 4 (1993), 329-334.

5）貴家恒男：複合材料の耐放射線性研究の現状，1 ンスペック，12，(1987 夏号)，22-28.

6) 宇田川昂, 貴家恒男, 伊藤 洋, 萩原 幸 : 高分 子論文集, 44, 8 (1987)，631-639.

7）宇田川昂：高分子 論 文 集，49，6 (1992)，551553. 